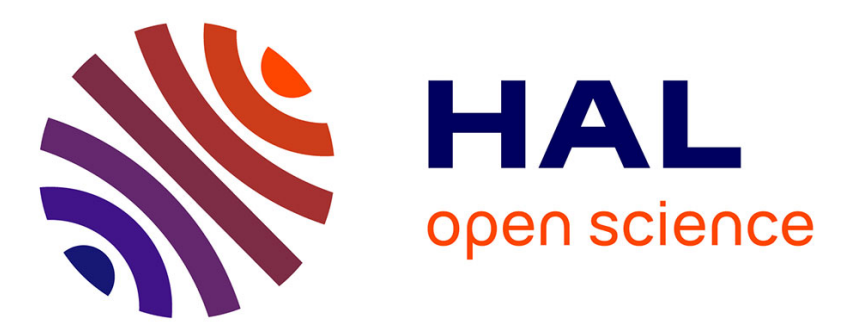

\title{
Farmer Compensation and its Consequences for Environmental Benefit Provision in the Higher Level Stewardship Scheme
}

\author{
Emmanuelle Quillérou, Robert W. Fraser, Iain M. Fraser
}

\section{To cite this version:}

Emmanuelle Quillérou, Robert W. Fraser, Iain M. Fraser. Farmer Compensation and its Consequences for Environmental Benefit Provision in the Higher Level Stewardship Scheme. Journal of Agricultural Economics, 2011, 62 (2), pp.330-339. 10.1111/j.1477-9552.2011.00291.x . hal-01954573

\section{HAL Id: hal-01954573 https://hal.science/hal-01954573}

Submitted on 18 Feb 2019

HAL is a multi-disciplinary open access archive for the deposit and dissemination of scientific research documents, whether they are published or not. The documents may come from teaching and research institutions in France or abroad, or from public or private research centers.
L'archive ouverte pluridisciplinaire HAL, est destinée au dépôt et à la diffusion de documents scientifiques de niveau recherche, publiés ou non, émanant des établissements d'enseignement et de recherche français ou étrangers, des laboratoires publics ou privés. 


\title{
Farmer compensation and its consequences for environmental benefit provision in the Higher Level Stewardship Scheme
}

\author{
Emmanuelle Quillérou ${ }^{a}{ }^{*}$, Rob W. Fraser ${ }^{b, c}$, and lain M. Fraser ${ }^{b}$
}

\begin{abstract}
a Kent Business School, University of Kent, Canterbury, CT2 7NZ, United Kingdom ${ }^{b}$ School of Economics, University of Kent, Canterbury, CT2 7NZ, United Kingdom

$c$ University of Western Australia
\end{abstract}

\section{* Corresponding author}

E-mail: E.Quillerou@kent.ac.uk 


\title{
Farmer compensation and its consequences for environmental benefit provision in the Higher Level Stewardship Scheme
}

\author{
Emmanuelle Quillérou, Rob Fraser and lain Fraser ${ }^{1}$
}

\begin{abstract}
The Environmental Stewardship Scheme (ESS) provides payments to farmers for the provision of environmental services based on forgone agricultural income. Consequently, farmers with a relatively low opportunity cost of agricultural land will be particularly attracted to applying for entry into the ESS within a given payment region. This paper tests whether there exists a significant relationship between Higher Level Stewardship (HLS) Scheme entry and agricultural yields. Empirically HLS participation is found negatively related to cereal yields at the farm level. This could be associated with "auspicious selection" of land into the Scheme, with greater "value for money" provided by the higher entry of land with lower agricultural forgone income but higher environmental benefit within the region.
\end{abstract}

Keywords: agri-environment, Environmental Stewardship, principal-agent, contract JEL codes: D78; D82; H44; Q18; Q58

\footnotetext{
1 Emmanuelle Quillérou is the contact author (emmanuelle quillerou@yahoo.fr). This research was conducted while she was at the Kent Business School, University of Kent, Canterbury, CT2 7PE, United Kingdom. Rob Fraser is Professor of Agricultural Economics at the School of Economics of the University of Kent, and also Adjunct Professor of Agricultural and Resource Economics at the University of Western Australia. Iain Fraser is a Reader in Agri-Environmental Economics at the School of Economics, University of Kent, Canterbury, CT2 7NP, United Kingdom.

We are particularly grateful to the Editor in Chief, as well as to two anonymous reviewers for their very helpful comments on previous versions.
} 


\section{Introduction}

In Quillérou and Fraser (2010), we focused on the English Higher Level Stewardship (HLS) environmental Scheme's contract allocation between regions, where we showed that the budget constraint on total payments to farmers encourages the selection of land in 'low cost' regions. So long as 'low cost' regions provide similar environmental benefits to 'high cost' regions, the budget constraint on spending potentially improves overall cost-effectiveness. In this note we focus on an empirical assessment of farmers' HLS option selection for entry into the Scheme within a given payment region.

Since 1992, the Common Agricultural Policy has been subject to a series of reforms that have gradually transferred support from agricultural production toward the provision of environmental goods and services. Under the WTO, these payments are constrained to "the extra costs or loss of income involved in complying with the government programme" (Annex 2, Articles 1 and 12, WTO, 2009). Since 2005, the main agri-environmental scheme in England has been the Environmental Stewardship Scheme (ESS) (Defra, 2005). ESS is a national scheme composed of two tiers: the lower tier ELS/OELS (Entry Level Stewardship/Organic Entry Level Stewardship) Schemes with general agrienvironmental requirements; the higher tier HLS Scheme with more specific environmental requirements and higher levels of environmental commitment.

The ELS Scheme employs a whole-farm approach. Any farmer and landowner can participate and receive a 5-year contract (Defra, 2005). The ELS Scheme relies on self-selection by farmers of the environmental options they will undertake from a pre-specified "menu". For each option selected there is a corresponding number of points reflecting the nationally estimated agricultural income forgone (Defra, 2005). An ELS (OELS) Scheme agreement is guaranteed providing a farmer meets a 30-point (60-point) target per hectare. This in turn yields a corresponding payment of $£ 30 /$ ha ( $£ 60 / \mathrm{ha}$ ) (Defra, 2005).

The higher tier HLS Scheme targets more complex types of agri-environmental activities and land use management (Defra, 2005). In common with the ELS Scheme, it is left to an individual farmer to select farm specific land management options from a pre-specified set for each of which there is a predetermined fixed per unit payment. However, entry into the HLS Scheme is at the discretion of Natural England, the operating authority. Natural England selects applications by employing a scoring and threshold mechanism, selecting contracts that provide "good 'value for money' " (Defra, 2005).

The spatial differentiation, from 2005 to 2007, has been based on the 159 Joint Character Areas, areas of the English countryside with "similar" landscape character, each with a specific association of wildlife and natural features (Defra, 2005, 2006). Each of the Joint Character Areas has a corresponding set of environmental targets against which bids submitted to the HLS Scheme are scored, with additional points for enhancing a Site of Special Scientific Interest (SSSI) or a Scheduled Monument (Defra, 2005). All scored applications are then pooled for all Joint Character Areas within the same administrative region (roughly corresponding to Government Office Regions). Finally, a threshold entry decision criterion (i.e. cut-off score) is set for all Joint Character Areas within the same 
administrative region, reflecting the available budget for the Scheme, and all applications that attain a score greater than the regional threshold are offered a contract. The scheme targeting was revised in 2008 with the adoption of a map-based targeting overlapping the Joint Character Areas.

Based on recent evidence, the relationship between the forgone agricultural income (the approximate basis for the HLS Scheme menu prices) and the environmental physical benefits provided by conservation schemes seems to be limited at best (Naidoo and Iwamura, 2007, Haines-Young, 2009), or negative (Goulding, 2000, Dallimer et al., 2009, Hanley et al., 2009, Kleijn et al., 2009). This suggests a negative correlation between the forgone agricultural income and social environmental value. If so, the HLS Scheme is incentive compatible and is likely to be associated with an "auspicious selection" ${ }^{2}$ of land, with higher "value for money" (Defra, 2005), contrary to Fraser and Fraser (2006) and Fraser(2009).

To date, the economics literature on adverse selection in agri-environmental scheme design and implementation has been based on theoretical analyses of contract design mechanisms (Wu and Babcock, 1996, Moxey et al., 1999, Feng, 2007). There currently exists very little research that has attempted to examine this information problem empirically. The examples that do exist in the literature have considered policy cost-effectiveness issues relating to auction mechanisms (Stoneham et al., 2003, Latacz-Lohmann and Schilizzi, 2005, Connor et al., 2008, Windle and Rolfe, 2008) or (spatial) benefit targeting (Langpap et al., 2008, Hajkowicz, 2009, Merckx et al., 2009). One exception (Quillérou and Fraser, 2010) focused on HLS Scheme contract allocation between (landscape) regions.

In the next section (Section 2), we test whether a significant relationship exists between HLS Scheme entry and agricultural yields. We then discuss the consequences of this finding for environmental benefit provision, and the achievement of "good 'value for money' " (Defra, 2005). The final section of the paper offers a summary and conclusions.

\section{Data, Analysis and Results}

In this Section we test whether a significant relationship exists between HLS Scheme entry and agricultural yields.

The farm-level data used for this analysis comes from a survey collected and described in Bailey et al. (2009). This survey includes various farm characteristics (size, farm type), agricultural characteristics (crops, yields, prices, self-assessed profitability relative to similar farms in the same area), environmental scheme characteristics (in particular HLS, ELS, Countryside Stewardship Scheme, Environmentally Sensitive Area scheme), socio-economic characteristics (farm status of respondents, in full-time or part-time farming, years in farming), and postcode (area code only). Agricultural yields for the complete dataset have been found to be in line with national averages by Bailey et al. (2009),

\footnotetext{
${ }^{2}$ We are grateful to an anonymous reviewer for pointing this out and suggesting this term.
} 
so the data can be considered reasonably representative. The majority of data are arable or mixed farms. There has been a relatively high uptake of the HLS Scheme by cereal farms: $27 \%$ by numbers of farmers and $40 \%$ of the area (Boatman et al., 2007). For the sample data each farm was spatially matched to government office regions using its postcode area (using ArcGIS, ESRI, 2006). Postcode areas often overlap across several government office regions, so only entries that could be allocated to a single government office region were retained for the analysis. This yielded a sample of 135 observations.

$58 \%$ of the sample farms are in the HLS Scheme or intend to enter in the next three years, which is much higher than the national average (0.5\% of holdings in 2006, Boatman et al., 2007). This overrepresentation of HLS Scheme farmers could limit the generalisation of the results to the full farmer population for this empirical analysis. Differences in yield averages between crops are mostly due to the number of zero-observations, and not to a difference in the range of yields. Sample observations were mostly in the South East and the South West, which is in keeping with actual HLS Scheme contracts (Boatman et al., 2007). But, our sample has the lowest number of farms in the North West instead of Yorkshire and the Humber.

Although the preferred dependent variable is the quantity of land entered into the HLS Scheme per farm, these data are not available from this dataset. An indicator of whether farms were already entered into the HLS Scheme, or intended to enter within the next three years, was used. Therefore, a binary variable (i.e. HLS Scheme entry/non-entry) was constructed to include both current entries and intended entries. All intended entries were considered as effective entries, as most farms were already enrolled into the Environmentally Sensitive Area Scheme or Countryside Stewardship Scheme (both schemes have now been replaced by the Environmental Stewardship), or into the ELS Scheme (lower tier).

In terms of independent variables farm size (Total farm area) was included, as this has previously been found to potentially influence participation in agri-environmental schemes (Bonnieux et al., 1998, Boatman et al., 2007, Defrancesco et al., 2008, Hynes and Garvey, 2009). More generally, the adoption of the latest English agri-environmental schemes has been found to depend on farm structural characteristics and farm size. For example, these agri-environmental schemes are often less attractive for intensive production systems and smaller holdings. Also, scheme participation tends to be higher for cereal farms (Boatman et al., 2007).

The number of arable crops (Number of crops) was employed as an explanatory variable, as the sum of the types of wheat and barley cropped. The number of farm activities (Number of farm activities) was derived from the types of farm recorded in the dataset (one activity for arable only or livestock only farms, 2 for mixed farms), as this is expected to influence participation (Boatman et al., 2007, Hynes and Garvey, 2009).

Yield variables for different cereal crops (i.e. wheat for milling or animal feed, barley for animal feed) and other crops (as surveyed) were included as explanatory variables. 
A question asking farmers to self-assess their relative level of profitability was included in the questionnaire. This information has been used by employing two dummy variables that takes the form Less Profitable and More Profitable, with the classification Equally Profitable retained as the reference level. Farmer status was included in the analysis as a dummy variable (one if the farm manager, and zero if the farm owner or the tenant farmer). To date in the literature there is mixed evidence regarding the impact of farm tenure on Scheme participation (see Wynn et al., 2001, Defrancesco et al., 2008, Hynes and Garvey, 2009). We also included a dummy variable of whether respondents were in fulltime agriculture (Fulltime) as opposed to part-time farming or agribusiness.

The number of years (Year decider) respondents have been the main decision-makers on the farm is included as an explanatory variable, as farmer age has been found a significant explanatory variable in previous studies (e.g. Bonnieux et al., 1998, Wynn et al., 2001, Hynes and Garvey, 2009). Education level, measured as a category variable, is also included, which has been found to be negatively related to participation in agri-environmental schemes by previous research studies (Bonnieux et al., 1998, Defrancesco et al., 2008).

Finally, government office region dummies were included so as to control for between-region variations (with the East of England region taken as reference), of agricultural and environmental characteristics, and of different HLS Scheme budgets.

In summary, the explanatory variables used to determine entry to the HLS Scheme are: total farm area; number of different crops (for wheat and barley); number of farm activities; yields of three crops (milling wheat, feed wheat, barley); relative level of profitability (dummies); type of farmer (farm manager by reference to farm owner and tenant farmer); number of years as main decision-maker (Year decider); government office regions (dummies). A statistical summary of the variables employed is reported in Annex 13 .

Given the form of the dependent variable, we employed limited dependent variable regression methods. A logit regression model was estimated with the marginal effects reported in Table 1 . These are calculated at the point of the sample mean.

The pseudo $R^{2}$ value is low (16\% - Table 1), as expected for cross-sectional data. The Likelihood Ratio (LR) $\mathrm{Chi}^{2}$ test statistic is significantly different from zero ( $p$-value of 0.0859 ), suggesting the parameters are jointly significant. Nevertheless, only five of the explanatory variables are significantly related to entry to the HLS Scheme.

\footnotetext{
${ }^{3}$ All estimations were performed using Stata 9 (StataCorp, 2005). All pairs of variables display very low correlation coefficients, with most coefficients less than $20 \%$ for each pair of variables. The correlation coefficient between the number of farm activities and each of the crop yields is between $40 \%$ and $50 \%$. The correlation coefficient between Total farm area and the Farm manager dummy is the highest at around $52 \%$. These coefficients are reported here in relation to the possible existence of collinearity, which appears limited.
} 
The total farm area and number of crops (structural factors) have a significant positive influence on HLS Scheme entry (respectively at a $10 \%$ and $5 \%$ level of significance), which is consistent with the findings of Boatman et al. (2007). The marginal effect for total farm area is, however, very low $(0.0 \%$ increase in HLS participation for each extra hectare of farm land).

Table 1: Logit regression results of HLS Scheme participation

\begin{tabular}{|c|c|c|c|}
\hline \multirow[b]{2}{*}{ Variable } & \multicolumn{3}{|c|}{ Marginal effects } \\
\hline & $d y / d x$ & & Std. Err. \\
\hline Total farm area & 0.000 & * & $(0.000)$ \\
\hline Number of crops & 0.216 & ** & $(0.098)$ \\
\hline Number of farm activities & 0.143 & & $(0.109)$ \\
\hline Yield wheat milling & -0.018 & & $(0.017)$ \\
\hline Yield wheat feed & -0.033 & ** & $(0.015)$ \\
\hline Yield barley feed & -0.035 & * & $(0.018)$ \\
\hline Yield other crops & 0.005 & & $(0.008)$ \\
\hline Less Profitable & 0.019 & & $(0.161)$ \\
\hline More Profitable & -0.086 & & $(0.128)$ \\
\hline Farm manager & -0.157 & & $(0.181)$ \\
\hline Fulltime & 0.312 & ** & $(0.153)$ \\
\hline Year decider & -0.003 & & $(0.005)$ \\
\hline Education & 0.041 & & $(0.048)$ \\
\hline East Midlands & -0.090 & & $(0.168)$ \\
\hline North East & 0.215 & & $(0.197)$ \\
\hline North West & 0.114 & & $(0.282)$ \\
\hline South East & -0.014 & & $(0.163)$ \\
\hline South West & -0.233 & & $(0.151)$ \\
\hline West Midlands & -0.181 & & $(0.212)$ \\
\hline Yorkshire and the Humber & -0.078 & & $(0.190)$ \\
\hline Number of observations & 135 & & \\
\hline Log likelihood & -77.39 & & \\
\hline LR Chi2 (20) & 29.10 & * & \\
\hline Pseudo $\mathbf{R}^{2}$ & 0.158 & & \\
\hline
\end{tabular}

$\left({ }^{*}\right.$ : significant at a $10 \%$ level; ${ }^{* *}$ : significant at a $5 \%$ level; ${ }^{* * *}$ : significant at a $1 \%$ level of significance)

The marginal effects for yields of wheat and barley for feed crops are also found statistically significant (respectively at a $5 \%$ and $10 \%$ level of significance). Being in fulltime agriculture has a positive influence on HLS Scheme entry (at a $5 \%$ level of significance), contrary to the findings of Hynes et al. 
(2008) for the Irish REPS. This discrepancy could be due to the HLS Scheme being designed as the highest tier of the ESS, globally more environmentally demanding and with 10-year agreements. It could also be down to differences in farming in England and Ireland, or to differences in Scheme design especially with respect the types of environmental goods and services being valued or the type of farming implicitly supported.

Most of the explanatory variables suggested in the literature have not been found significant here. This would suggest that there is no simple and reliable theoretical model of participation appropriate for this dataset

In summary, entry (i.e., participation) in the HLS Scheme significantly decreases with increasing yields of crops for feed wheat and barley within the different government regions (as no regional dummy was found significant). This result implies there is some evidence of farmers entering land of lower agricultural quality (yield) than average into the HLS Scheme. This finding is consistent with the results of studies by Shoemaker (1989), Osterberg (1999, cited by Ferraro, 2008), Osterburg and Nieberg (1999, cited by Latacz-Lohmann and Schilizzi, 2005), and Osterburg (2001), which showed higher participation rates in regions of poorer soils, lower yields and a lower share of intensive crops, and a generally lower intensity of land use (hill areas). In addition, this finding is consistent with the most recent studies of higher participation in the Irish agri-environmental scheme (REPS) for more extensive systems of farming (less environmentally degrading) or for lower soil quality (Hynes and Garvey, 2009).

The study of Rygnestad and Fraser (1996) showed that farmers had an incentive to set-aside their lower yielding land in order to minimise the impact of the set-aside requirement on their production income. This "adverse selection" of lower yielding land by farmers reduced the cost-effectiveness of the policy's attempts to reduce output. However, Rygnestad and Fraser (1996) also showed that this lower yielding land exhibited greater potential for nitrate leaching from fertiliser application, resulting in an "auspicious selection" of land for set-aside from the perspective of environmental benefits.

In the context of this study, such "auspicious selection" would also be occurring if the lower yielding land being offered for participation in the HLS Scheme was similarly providing a greater environmental benefit in terms of reduced nitrate leaching or enhanced habitat provision than other land not being offered for participation. Moreover, if such a negative correlation between agricultural income and environmental benefit could be demonstrated to apply for land selected into the HLS Scheme, then this finding would imply improved cost-effectiveness of the Scheme. This would further support the findings of Quillérou and Fraser (2010) regarding the beneficial impact of design features of the HLS Scheme on its cost-effectiveness. 


\section{Conclusion}

This paper has examined the selection by farmers of land for entry into the HLS Scheme within a region of common payments for participation. Section 2 of this paper focused on determinants of farmers' participation in the HLS Scheme, including cereal yields.

The results show that HLS Scheme participation as measured here is not well explained by the variation in most of the explanatory variables suggested in the literature. In our sample, participation is significantly influenced by the yields of feed wheat and barley, total farm area, the number of crops, and whether farmers are in full-time agriculture. Within a given region, farmer participation in the HLS Scheme is significantly negatively related to farm yields. These results might, however, not be representative of the whole farmer population, in relation to the over-representation of HLS Scheme farmers in the sample. The regional effects might also not be found significant here because of the dataset regional spread and structure.

The same type of analysis could be applied to types of options other than just the arable ones (e.g. for grassland options). It would also be interesting to apply the same approach, controlling for landscape regions (lower geographical level than government office regions), to test whether the relationship holds at a lower level of analysis.

Nevertheless, the Scheme objective - the provision of "good 'value for money' " (Defra, 2005) - would be achieved so long as there is a negative correlation between environmental benefit and the opportunity cost of provision (yield), as suggested by empirical studies. In this case, the Scheme would result in "auspicious" rather than adverse selection, with lower yielding/higher environmental benefit land being enrolled in the HLS Scheme. In addition, this within-region finding would further support the between-region design benefit features of the HLS Scheme identified by Quillérou and Fraser (2010).

\section{References}

Bailey, A. S., M. Bertaglia, I. M. Fraser, A. Sharma and E. Douarin (2009) Integrated pest management portfolios in UK arable farming: results of a farmer survey. Pest management science, 65(9), 1030-1039.

Boatman, N., N. Jones, D. Garthwaite and J. Bishop (2007) Evaluation of the introduction and operation of Environmental Stewardship: Final report. Defra project No. MA01028. York: Central Science Laboratory. Available from: http://randd.defra.gov.uk/Document.aspx?Document=MA01028_6197_FRP.pdf [Accessed 04/02/2008].

Bonnieux, F., Rainelli, P. and Vermersch, D. (1998) Estimating the Supply of Environmental Benefits by Agriculture: A French Case Study. Environmental and Resource Economics, 11(2), 135-153. 
Connor, J. D., Ward, J. R. and Bryan, B. (2008) Exploring the cost effectiveness of land conservation auctions and payment policies. Australian Journal of Agricultural and Resource Economics, 52(3), 303-319.

Dallimer, M., Acs, S., Hanley, N., Wilson, P., Gaston, K. J. and Armsworth, P. (2009) What explains property-level variation in avian diversity? An inter-disciplinary approach. Journal of Applied Ecology, 46(3), 647-656.

Defra (2005). Higher Level Stewardship handbook: Terms and conditions and how to apply. PB10382. Department for Environment, Food and Rural Affairs. Available from: http://www.defra.gov.uk/erdp/pdfs/es/hls-handbook.pdf [Accessed 22/06/2007].

Defra (2006) Targeting Statements. Department for Environment, Food and Rural Affairs. Available from: http://www.defra.gov.uk/erdp/schemes/jca-ts/default.htm [Accessed 30/01/2008].

Defrancesco, E., Gatto, P., Runge, F. and Trestini, S. (2008) Factors Affecting Farmers' Participation in Agri-environmental Measures: A Northern Italian Perspective. Journal of Agricultural Economics, 59(1), 114-131.

ESRI (2006) ArcGIS Desktop: Release 9.2.

Feng, H. (2007). Green payments and dual policy goals. Journal of Environmental Economics and Management, 54(3), 323-335.

Ferraro, P. J. (2008) Asymmetric Information and Contract Design for Payments for Environmental Services. Ecological Economics, 65(4), 810-821.

Fraser, R. (2009) Land Heterogeneity, Agricultural Income Forgone and Environmental Benefit: An Assessment of Incentive Compatibility Problems in Environmental Stewardship Schemes. Journal of Agricultural Economics, 60(1), 190-201.

Fraser, R. and I. Fraser (2006) The Implications of Information Asymmetries for Agri-Environmental Policies. Paper presented to the OECD Workshop on Information Deficiencies in Agrienvironmental Policies, June, Paris. Available from: www.oecd.org/agr/meet/idap.

Goulding, K. (2000) Nitrate leaching from arable and horticultural land. Soil Use and Management, 16, 145-151.

Hajkowicz, S. (2009) The evolution of Australia's natural resource management programs: Towards improved targeting and evaluation of investments. Land Use Policy, 26(2), 471-478.

Hanley, N., Tinch, D., Angelopoulos, K., Davies, A., Barbier, E.B. and Watson, F. (2009) What drives long-run biodiversity change? New insights from combining economics, palaeoecology and environmental history. Journal of Environmental Economics and Management, 57(1), 5-20

Haines-Young, R. (2009) Land use and Biodiversity relationships. Land Use Policy, 26(Supplement 1), S178-S186.

Hynes, S., Farrelly, N., Murphy, E. and O'Donoghue, C. (2008) Modelling habitat conservation and participation in agri-environmental schemes: A spatial microsimulation approach. Ecological Economics, 66(2-3), 258-269.

Hynes, S. and Garvey, E. (2009) Modelling Farmers' Participation in an Agri-environmental Scheme using Panel Data: An Application to the Rural Environment Protection Scheme in Ireland. Journal of Agricultural Economics, 60(3), 546-562.

Kleijn, D., Kohler, F., Báldi, A., Batáry, P., Concepción, E. D., Clough, Y., Díaz, M., Gabriel, D., Holzschuh, A., Knop, E., Kovács, A., Marshall, E. J. P., Tscharntke, T. and Verhulst, J. (2009) 
On the relationship between farmland biodiversity and land-use intensity in Europe.

Proceedings of the Royal Society B, 276, 903-909.

Langpap, C., Hascic, I. and Wu, J. (2008) Protecting Watershed Ecosystems through Targeted Local

Land Use Policies. American Journal of Agricultural Economics, 90(3), 684-700.

Latacz-Lohmann, U. and S. Schilizzi (2005) Auctions for Conservation Contracts: A Review of the Theoretical and Empirical Literature. Report to the Scottish Executive Environment and Rural Affairs Department Project No: UKL/001/05. Available from: http://www.scotland.gov.uk/Resource/Doc/93853/0022574.pdf [Accessed 14/01/2008].

Merckx, T., Feber, R. E., Riordan, P., Townsend, M. C., Bourn, N. A. D., Parsons, M. S. and Macdonald, D. W. (2009) Optimizing the biodiversity gain from agri-environment schemes. Agriculture, Ecosystems \& Environment, 130(3-4), 177-182.

Moxey, A., B. White and A. Ozanne (1999). Efficient contract design for agri-environment policy. Journal of Agricultural Economics, 50(2), 187-202.

Naidoo, R. and Iwamura, T. (2007) Global-scale mapping of economic benefits from agricultural lands: Implications for conservation priorities. Biological Conservation, 140(1-2), 40-49.

Osterberg, B. (1999) Agri-environment programmes in Germany - implementation, acceptance and aspects of their evaluation. 1st Workshop on the Management and Monitoring of AgriEnvironment Schemes, 23-24 November, Ispra, Italy.

Osterburg, B. (2001) Agri-environmental Programs and the Use of Soil Conservation Measures in Germany In: D. E. Stott, R. H. Mohtar and G. C. Steinhardt (ed.) Sustaining the Global Farm Selected papers from the 10th International Soil Conservation Organization Meeting, May 2429, 1999. West Lafayette, International Soil Conservation Organization in cooperation with the USDA and Purdue University. pp. 112-118.

Osterburg, B. and Nieberg, H. (1999) Regional acceptance of agri-environmental schemes and their impacts on production, incomes and environment - the case of Germany. IX European Congress of Agricultural Economists, 24-28 August, Warsaw, Poland.

Quillérou, E. and Fraser, R. (2010). Adverse Selection in the Environmental Stewardship Scheme: Does the Higher Level Stewardship Scheme Design Reduce Adverse Selection? Journal of Agricultural Economics, 61(2): 369-380.

Rygnestad, H. L. and Fraser, R. W. (1996) Land heterogeneity and the effectiveness of CAP setaside. Journal of Agricultural Economics, 47(2), 255-260.

Shoemaker, R. (1989) Agricultural Land Values and Rents under the Conservation Reserve Program. Land Economics, 65(2), 131-137.

Stoneham, G., Chaudhri, V., Ha, A. and Strappazzon, L. (2003) Auctions for conservation contracts: an empirical examination of Victoria's BushTender trial. Australian Journal of Agricultural and Resource Economics, 47(4), 477-500.

StataCorp (2005) Stata Statistical Software: Release 9. College Station, TX: StataCorp LP. Windle, J. and Rolfe, J. (2008) Exploring the efficiencies of using competitive tenders over fixed price grants to protect biodiversity in Australian rangelands. Land Use Policy, 25(3), 388-398.

WTO (2009) Legal texts: Marrakesh agreement. Available from: http://www.wto.org/english/docs_e/legal_e/14-ag_02_e.htm [Accessed 15/12/2009]. 
Wu, J. and B. A. Babcock (1996). Contract Design for the Purchase of Environmental Goods from

Agriculture. American Journal of Agricultural Economics, 78(4), 935-945.

Wynn, G., Crabtree, B. and Potts, J. (2001) Modelling Farmer Entry into the Environmentally Sensitive Area Schemes in Scotland. Journal of Agricultural Economics, 52(1), 65-82.

\section{Annex 1.}

Table 2: Variable description and statistics of regression sample $(\mathrm{N}=135)$

\begin{tabular}{|c|c|c|c|c|c|}
\hline Variable & Units & Mean & Std. Dev & Min & Max \\
\hline HLS entry & dummy & 0.58 & 0.50 & 0 & 1 \\
\hline Total farm area & ha & 385.21 & 439.72 & 5.26 & $2,374.00$ \\
\hline Number of crops & & 1.70 & 0.91 & 0 & 4 \\
\hline Number of farm activities & & 1.50 & 0.50 & 1 & 2 \\
\hline Yield wheat milling & t/ha & 3.62 & 4.26 & 0 & 10.20 \\
\hline Yield wheat feed & t/ha & 5.36 & 4.25 & 0 & 11.25 \\
\hline Yield barley feed & t/ha & 2.44 & 3.43 & 0 & 10.00 \\
\hline Yield other crops & t/ha & 2.97 & 8.90 & 0 & 101.00 \\
\hline Less Profitable & dummy & 0.11 & 0.32 & 0 & 1 \\
\hline More Profitable & dummy & 0.24 & 0.43 & 0 & 1 \\
\hline Farm manager & dummy & 0.14 & 0.35 & 0 & 1 \\
\hline Fulltime & dummy & 0.88 & 0.32 & 0 & 1 \\
\hline Year decider & years & 21.80 & 11.58 & 0 & 55 \\
\hline Education & categories & 3.78 & 1.10 & 1 & 5 \\
\hline East Midlands & dummy & 0.13 & 0.33 & 0 & 1 \\
\hline North East & dummy & 0.07 & 0.25 & 0 & 1 \\
\hline North West & dummy & 0.02 & 0.15 & 0 & 1 \\
\hline South East & dummy & 0.14 & 0.35 & 0 & 1 \\
\hline South West & dummy & 0.19 & 0.40 & 0 & 1 \\
\hline West Midlands & dummy & 0.06 & 0.24 & 0 & 1 \\
\hline Yorkshire and the Humber & dummy & 0.10 & 0.30 & 0 & 1 \\
\hline
\end{tabular}

